\title{
SUSTAINABLE WASTE-TREATMENT PROCEDURE FOR THE SPENT POTLINING (SPL) FROM ALUMINIUM PRODUCTION
}

\author{
TRAJNOSTNI POSTOPEK OBDELAVE ODPADKOV SPL IZ \\ PROIZVODNJE ALUMINIJA
}

\author{
Blaž Tropenauer ${ }^{1}$, Dušan Klinar², Niko Samec³, Janvit Golob ${ }^{4}$, Jože Kortnik ${ }^{5}$ \\ 1TALUM d.d. Kidričevo, Tovarniška cesta 10, 2325 Kidričevo, Slovenia \\ ${ }^{2}$ Scientific Research Centre BISTRA Ptuj, Slovenski trg 6, 2250 Ptuj, Slovenia, \\ ${ }^{3}$ University of Maribor Faculty of mechanical engineering, Smetanova ulica 17, 2000 Maribor, Slovenia \\ ${ }^{4}$ Univerza of Ljubljana, Faculty of Chemistry and Chemical Technology, Večna pot 113, 1000 Ljubljana, Slovenia \\ ${ }^{5}$ University of Ljubljana Faculty of Natural Sciences and Engineering, Aškerčeva ulica 12, 1000 Ljubljana, Slovenia
}

Prejem rokopisa - received: 2018-07-13; sprejem za objavo - accepted for publication: 2018-11-29

doi:10.17222/mit.2018.147

\begin{abstract}
Some different possible solutions to the problem of industrial waste originating from primary aluminium production (also known as SPL) have been investigated. The latest techniques to treat SPL are presented, with the highlight being flotation and chemical treatment technology. Laboratory tests confirmed that the SPL treatment model is not feasible and viable within partial solutions. Only the systematically achieved solution can be in accordance with a wide range of contemporary demands. Partly, the cause is the allotropic form of the carbon cathodes produced and partly also the impurities in the waste material that prevent an effective one-phase treatment. Laboratory investigations of reactive extraction open up the possibilities for wide SPL material utilization. The preliminary inquiry confirms that the interdisciplinary approach leads to open solutions leading to possible market interest or generated value from the waste as the main goal of a circular economy.

Keywords: spent pot line, waste treatment, flotation, alkaline-acidic treatment

Raziskane so bile nekatere možne rešitve za problem industrijskih odpadkov, ki izvirajo iz primarne proizvodnje aluminija (znani tudi kot SPL). Predstavljene so najnovejše tehnike za predelavo SPL s poudarkom na tehnologiji flotacije in kemične obdelave. Laboratorijski testi so potrdili, da model predelave SPL ne bi bil izvedljiv z delnimi rešitvami. Sistematično dosežena rešitev lahko ustreza le širokemu obsegu sodobnih zahtev. Delno je vzrok alotropna oblika proizvedenih ogljikovih katod in delno tudi nečistoče $\mathrm{v}$ odpadnem materialu, ki onemogočajo učinkovito enofazno obdelavo. Laboratorijske preiskave reaktivne ekstrakcije v veliki meri odpirajo možnosti za materialno izrabo SPL. Preliminarna poizvedba potrjuje, da interdisciplinaren pristop vodi k odprtim rešitvam, ki omogočajo tržni interes oziroma ustvarjeno vrednost iz odpadka, kot glavni cilj krožnega gospodarstva.
\end{abstract}

Ključne besede: izrabljene katodne obloge, obdelava odpadkov, flotacija, alkalno kisla obdelava

\section{INTRODUCTION}

Throughout the history of aluminium production, the industry has searched for a feasible and environmentally friendly solution for the treatment of spent potlining (SPL) as a waste product of the primary aluminium production process. SPL represents a basic part, i.e., the pot where melt of electrolyte and molten aluminium are kept during the electrolysis process, where the pot can last from 6 to 9 years. An SPL viable treatment is a global challenge for the primary aluminium industry, as is declared as a mixed hazardous waste that contains a first cut as mainly carbonaceous and a second cut as mainly refractories materials.

\subsection{Origins and challenges of SPL}

At the end of the electrolysis cell life, the allowed iron and silicon concentration limits in the electrolyte are exceeded and the bottom part of the cell must be

*Corresponding author e-mail:

blaztropenauer@gmail.com renewed. The SPL bottom part is lifted and transported to a dedicated concrete pit. In the disassembly process five major parts appear: the cryolite cover, the aluminium layer, the carbon conductor layer, the functional bricks and the metal frame. A major part of the cryolite is taken back to the process. The metal frame is renewed and new cathode blocks with chamotte and insulation bricks are lined up to form a new cathode. The spent carbon cathode and the functional bricks part remain as a waste product (Figure 1). The industrial naming for the carbon waste part is "first cut" as this part is the first to be stamped off. Analogically, after the first cut is collected, the bricks are on the turn as the so-called second cut. All the parts or cuts are toxic due to the impregnation with molten electrolyte during the operating period, containing leachable fluoride salts and cyanides.

The typical composition of the SPL waste is given in Table 1. However, it needs to be emphasized that these values can vary by up to 10 mass $\%$.

The main challenges that the innovative solution is responding to are the following: 

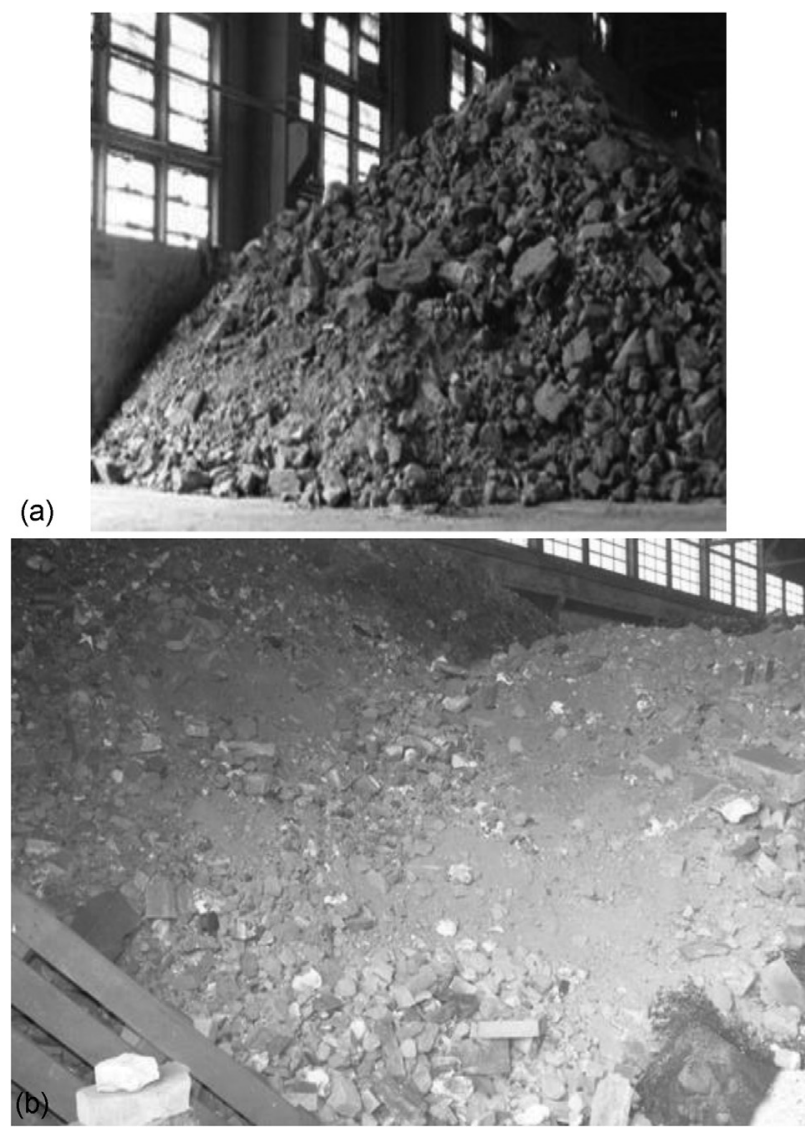

Figure 1: Typical repository of SPL waste in a warehouse: a) first-cut carbon part, b) the second cut

- A large volume of waste (problem of waste treatment, landfilling) that needs special storage and transportation requirements before landfilling and incineration

- The explosive and fire-hazardous nature of the SPL due to the potential development of explosive gases (ammonia and $\mathrm{C}_{2}$ hydro-carbon gases) and the high burning potential (difficulty in extinguishing the fire)

- The emission of dust particles due to the high fragility of the waste material, which contains hazardous particles (cyanides, fluorides, etc.)
- The treatment of the hazardous leachates due to the high level of hazardous soluble materials (approx. $25 \%(w / \%)$ fluorides and approx. $1 \%$ cyanides $)$

- The development of hazardous smoke in the case of the fire

- The corrosion properties of SPL due to the high $\mathrm{pH}$ (up to 13) due to the alkali metals and their oxides.

- The low social acceptance

\subsection{Treatment methods summary}

In principle, we can divide the SPL processing technologies into mechanical/physical, thermal and chemical. Mechanical refers to the separation of different fractions of waste, grinding, screening and other mechanical separation. For separation, specific properties of the material, such as solubility, density, chemical structure and surface properties (hydrophobicity-hydrophilicity, charge of the molecules, etc.) are used. These techniques are important primarily for the proper pre-preparation of the input material, thus achieving better efficiency in the main processes.

The best available technologies for non-ferrous metals describe many options to treat SPL: the re-use of SPL in cement production, as a carbonaceous substance in ironworks, as a secondary raw material (glass wool, salt slag) and as a substitute fuel. ${ }^{1}$ Øye describes both the thermal and chemical methods of SPL processing, emphasizing the challenges of salt separation, which accounts for as much as $30 \%$ of the total SPL content. ${ }^{2}$ Mikša compares the use of uncleaned SPL in the cement industry and thermoelectric power plants. ${ }^{3}$

In cement plants, the carbon part is used as a substitute for fuel, while the brick part is added to the production of clinker. ${ }^{4}$ Consequently, there is a noticeable decrease in the process temperature in the clinker production mass, which in turn reduces the consumption of heat per kilogram of clinker produced..$^{5}$ In ironworks, the carbon part is used as a fuel and a reducing agent. Fluorides increase the flow rate of the slag and lower the melting point, but at the same time they are also harmful (act corrosively) to the furnace wall. ${ }^{6}$

Table 1: Typical composition (in mass \%) of SPL waste; Source: Talum d.d. Slovenia

\begin{tabular}{|c|c|c|c|c|c|c|c|c|c|c|}
\hline $\begin{array}{c}\text { Amorphous } \\
\text { carbon }\end{array}$ & $\begin{array}{l}\text { Graphite } \\
\text { carbon }\end{array}$ & $\begin{array}{c}\text { Mullite } \\
\mathrm{Al}_{6} \mathrm{Si}_{2} \mathrm{O}_{13}\end{array}$ & $\begin{array}{l}\text { Cryolite } \\
\mathrm{Na}_{3} \mathrm{AlF}_{6}\end{array}$ & $\begin{array}{c}\text { Sodium } \\
\text { fluoride } \\
\mathrm{NaF}\end{array}$ & $\begin{array}{c}\text { Silicon } \\
\text { dioxide } \\
\mathrm{SiO}_{2}\end{array}$ & $\begin{array}{c}\text { Cordierite } \\
\left(\mathrm{K}, \mathrm{Mg}_{2} \mathrm{Al}_{3}\right. \\
\left(\mathrm{Si}_{5} \mathrm{AlO}_{18}\right)\end{array}$ & $\begin{array}{l}\text { Alumina } \\
\mathrm{Al}_{2} \mathrm{O}_{3}\end{array}$ & $\begin{array}{l}\text { Fluorite } \\
\mathrm{CaF}_{2}\end{array}$ & $\begin{array}{c}\text { Diaoyudaoi } \\
\text { te } \\
\mathrm{Na}_{2} \mathrm{Al}_{22} \mathrm{O}_{34}\end{array}$ & $\begin{array}{c}\text { Other (Ni, } \\
\text { Al, Mg) }\end{array}$ \\
\hline $24,7 \%$ & $19.6 \%$ & $19.0 \%$ & $12.9 \%$ & $9.6 \%$ & $4.0 \%$ & $3.8 \%$ & $2.6 \%$ & $2.0 \%$ & $1.1 \%$ & $0.6 \%$ \\
\hline \multicolumn{2}{|c|}{$44.3 \%$} & \multicolumn{9}{|c|}{$55.7 \%$ - Mineral part } \\
\hline
\end{tabular}

Table 2: Amounts of elements (in mass \%) after various procedures in the carbon part of the SPL processed waste

\begin{tabular}{|l|c|c|c|c|c|c|}
\hline \multicolumn{1}{|c|}{ Procedure } & $\mathrm{F}(\%)$ & $\mathrm{Na}(\%)$ & $\mathrm{Al}(\%)$ & $\mathrm{Si}(\%)$ & $\mathrm{Ca}(\%)$ & $\mathrm{Fe}(\%)$ \\
\hline Untreated SPL & 7.68 & 5.15 & 5.22 & 5.46 & 0.68 & 0.55 \\
\hline Water extraction (2x) & 4.85 & 2.41 & 5.48 & 5.88 & 0.81 & 0.62 \\
\hline Flotation (2xEkof) & 5.78 & 1.87 & 4.44 & 0.71 & 0.24 & 0.25 \\
\hline Alkaline (FC) & 2.70 & 2.56 & 2.11 & 0.94 & 0.27 \\
\hline Acidic (FC) & 1.00 & 1.90 & 0.99 & 0.87 & 0.29 & 0.07 \\
\hline
\end{tabular}


Chemical methods allow the separation of components and their purification in order to produce products that could be used either in their own processes or in other local industries. Some methods are based on the neutralization of the filtrate with calcium compounds (e.g., calcite $\left.\mathrm{CaCO}_{3}\right){ }^{7}$ Others focus on reuse and mostly predominate in the full exploitation of the raw-material base. They tend to extract cryolite and carbon $^{8,9}$ and useful fluoride compounds ${ }^{10,11}$ by dissolving in bases, acids or in solutions of aluminium salts. Some separation technologies use a two-step technique. First, they use aqueous purification to separate the soluble salts and then use compounds ( $\left.\mathrm{HF}, \mathrm{Al}\left(\mathrm{NO}_{3}\right)_{3}, \mathrm{HNO}_{3}, \mathrm{H}_{2} \mathrm{SO}_{4}\right)$ to form aluminium cations, which have a high affinity for fluorides to form stable and soluble fluoro-aluminium complexes with the purpose being to dissolve insoluble salts and form more useful types of filtrate compounds. ${ }^{10-13}$ Other techniques use three-stage separation, i.e., water purification, alkaline or acidic cleaning. ${ }^{8,14,15}$

Schönfelder reports on a flotation technique to separate carbon and silicate parts. ${ }^{16}$ The SPL waste is firstly exposed to sulphuric acid. In this process, the waste detoxifies, and at the same time $\mathrm{H}_{2} \mathrm{SiF}_{6}$ acid forms as a product. The detoxified SPL is then subjected to a flotation process where products such as carbon and silicates are obtained. The obtained $\mathrm{H}_{2} \mathrm{SiF}_{6}$ acid, in combination with the addition of $\mathrm{Al}(\mathrm{OH})_{3}$, produces the desired product of $\mathrm{AlF}_{3}$, which is used as a valuable reagent for the electrolysis process in aluminium production. Flotation was also reported to be a technology option in Chinese aluminium plants. ${ }^{16,17}$

\section{EXPERIMENTAL PART}

The main target of our research was focused on solving the old SPL waste problem, which requires the additional separation of carbon from the mineral (brick) part. The next goal is to create technologies for SPL treatment for the already-separated carbon and brick parts.

The proposed method does not include additional energy for reaction purposes. It is performed under standard ambient temperature and pressure conditions (SATP), i.e., $25^{\circ} \mathrm{C}, 298.15 \mathrm{~K}$ and $101.353 \mathrm{kPa}$.

The following four research methods were chosen for the experimental work:

- Mechanical/physical treatment of the sample

- Extraction of soluble salts

- Flotation separation process

- Alkaline and acidic chemical reactive leaching

The particle size of the material is important as it increases the surface area of the waste and thereby improves the hydrophilicity and promotes the leaching reactivity. For good flotation results, the size of the particles should range between $20 \mu \mathrm{m}$ and $300 \mu \mathrm{m} .{ }^{15}$ Graphite and sodium in the spent cathode make the spent cathode sticky, slippery and thus difficult to crush. ${ }^{18}$ The effective crushing process for a proposed plant and its economics are therefore of significant importance, so as to avoid jams and damage to equipment in the future.

In the next step, the water-extraction process ensures the dissolution of all the water-soluble salts (mostly $\mathrm{NaF}$ ). They account for as much as $30 \%$ of the sample mass. The resulting filtrate is detoxified with one of the methods for cyanide destruction. ${ }^{19}$

The clean slurry of the mixed carbon and bricks part is further subjected to flotation. The flotation reagents are oily and surface-active substances, which accumulate on the surface of the carbon and increase the hydrophobicity. The hydrophobic particles attach to the bubbles and are discharged as a foam. ${ }^{15}$

After the first-stage of the flotation slurry, the carbon part was subjected to a further alkali reactive extraction process, in order to extract the insoluble salts from the sample.

In the last step, the acid-reactive extraction process dissolved the insoluble compounds like $\mathrm{CaF}_{2}$ and $\mathrm{NaAl}_{11} \mathrm{O}_{17}$, where the carbon content $\left(\mathrm{C}_{\text {fix }}\right)$ rose to the desired level.

The scheme of the described procedure is presented in Figure 2.

Separately, a test to evaluate the extraction effectiveness with $\mathrm{HCl}$ and $\mathrm{AlF}_{3}$ solvents was performed.

The sample was extracted with the standard method (SIST EN 1247-4) where the ratio of liquid to solids $(\mathrm{L}: \mathrm{S})$ is kept in the range of 10:1.

\subsection{Analytical support}

All the samples for analysis were milled in Retsch MM 400 device. The resulting material for the flotation experiment weighed approx. $500 \mathrm{~g}$ with a $30-\mu \mathrm{m}$ average particle size. The sample was dried at $120{ }^{\circ} \mathrm{C}$ for $24 \mathrm{~h}$ to measure the carbon content using the standard ASTM $3172 / 73\left(800{ }^{\circ} \mathrm{C}\right.$ for $\left.5 \mathrm{~h}\right)$.

Qualitative and quantitative analysis with the Rietveld method. To obtain the mass fractions of the compounds in the samples, the following method was used. The samples were analysed using an X'Pert PRO x-ray powder diffractometer with $\mathrm{Cu}-\mathrm{K}_{\alpha 1}$ radiation in the $2 \theta$

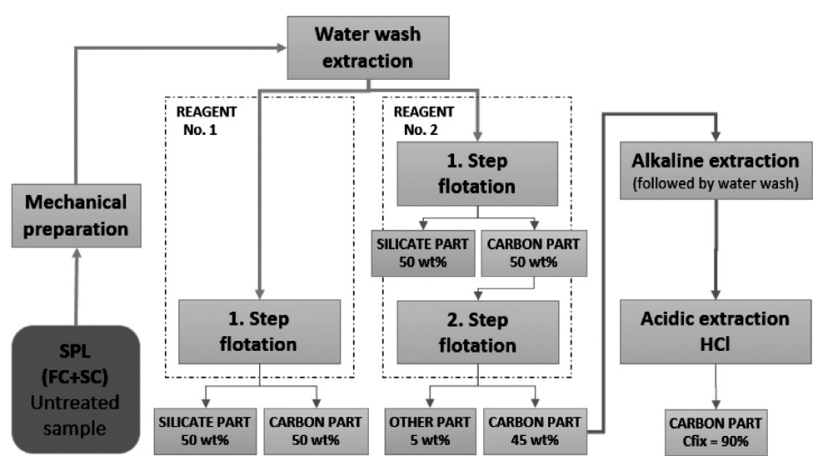

Figure 2: Schematic presentation of the described experimental procedure 
range from $5^{\circ}$ to $90^{\circ}$ and a $2 \theta$ step of $0.017^{\circ}$. Based on a qualitative analysis of the X-ray powder diffractograms with X'pert High Score Plus, the presence of several crystalline phases was identified, including phases in trace amounts. Through a quantitative analysis of the XRD diffractograms with the Rietveld method (TOPAS program), the mass proportions of the identified crystalline phases in the samples were determined. The estimated error of the calculation ranges from $3 \%$ to $10 \%$ for the phases with amounts below $5 \%$.

Scanning electron microscopy (SEM). Samples (approximately $5 \mathrm{mg}$ ) in the as-obtained form were positioned on aluminium carriers equipped with a carbon adhesive tape, inserted into the Zeiss SEM microscope chamber and analysed at various magnifications and acceleration voltages with three different detectors (inlens, SE2, EDS).

$X$-ray fluorescence $(X R F)$ was used for the quantitative element analysis. The samples were measured on a Thermo ARL Advant'X XRF with a copper tube operated at $50 \mathrm{kV}$ and $60 \mathrm{~mA}$. Standardless data analysis software Thermo Scientific Uniquant (v5,49; 2008) was used for a semi-quantitative content assessment of the elements (the carbon content, determined with a TGA, was calculated for a more accurate assessment).

$X$-ray diffraction (XRD) was used for solid crystal phase identification using a Panalytical Cubix3 X-Ray Diffractometer equipped with an $X^{\prime}$ Celerator detector. The copper tube was operated at $50 \mathrm{kV}$ and $40 \mathrm{~mA}$. The conditions used were $60 \mathrm{~min}^{-1}$ rotation, 10-80 2-theta, $0.011^{\circ}$ increment, $3 \mathrm{~s} /$ step time per step, $3.01 \mathrm{~min}$ scan time, with a $0.5 \mathrm{deg}$ fixed divergence slit. The resulting diffractograms were processed using the Panalytical HighScore+ 4.0 (2013). This software compared the measured XRD pattern with the International Centre for Diffraction Data (ICDD) database PDF-2 (2013) to find matches with known crystalline compounds.

Carbon content $\left(C_{f i x}\right)$ was measured on a Mettler Toledo TGA1 with STARe software. The sample was first heated to $950{ }^{\circ} \mathrm{C}$ under inert gas for a determination of the volatiles and then burnt in the air to a constant weight. $\mathrm{C}_{\mathrm{fix}}$ was calculated from the amounts of ash and volatiles.

\subsection{Samples preparation}

The experiments started with familiarization of the material. Many carbon-content and elemental analyses were carried in our laboratory in the past. The sample compositions were acquired with regards to the position in the cell (corner, side and bottom).

The samples were gathered from the Talum d.d. aluminium production plant. Large pieces of material were taken from the first and second cuts, in order to properly quantity the mass distribution in the cathode of the electrolytic cell (first cut $60 \%$, chamotte bricks $30 \%$ and isolating bricks $10 \%$ ). The chosen bulk samples were not contaminated with cryolite crust. In the process of crushing, some $70 \%$ of the sample mass was obtained by sieving. The sample was crushed in a metal moon, then in a jaw crusher and finally manually in a mortar. The sample was mixed in the mixing drum in order to achieve homogeneity. The resulting material for the flotation experiment had a weight of $500 \mathrm{~g}$ and an average particle size of $30 \mu \mathrm{m}$.

All the following extractions were carried out using the same methods. An L:S ratio of 10:1 was used for the extractions, the samples were stirred at a speed of $500 \mathrm{~min}^{-1}$ and at the end of the experimental time they were dried for $24 \mathrm{~h}$ in order to measure the carbon content. The sample was filtered with a blue-ribbon filter paper and dried for $24 \mathrm{~h}$ at $120{ }^{\circ} \mathrm{C}$ to determine the residual mass.

\subsection{Extraction of soluble salts}

As the SPL material is impregnated with soluble salts, a leaching procedure was performed first, since the ionized salts can disturb the effect of the flotation. Technological water was chosen as a solvent to imitate the fluoride and cyanide leaching in a real industry situation. The leaching procedure was performed for a maximum time of $24 \mathrm{~h}$, with the length of the individual steps after $10 \mathrm{~min}$ in the first hour, and then after hourly readings of the sample values.

\subsection{Froth flotation}

Froth flotation is a process for the selective separation of hydrophobic and hydrophilic materials. The flotation is normally performed in several stages to maximize the recovery of target minerals and the concentration of those minerals in the concentrate, while minimizing the energy input. In this work the flotation was carried out in a Denver flotation cell with two different agents.

The sample used in the froth flotation contained an average mixture of brick and carbon. It was washed twice and placed in a $1500-\mathrm{mL}$ metal container of the flotation cell.

\section{Flotation test with collector and froth reagent}

For the first flotation experiment, a collector agent was chosen (sodium ethyl xanthate $\left(\mathrm{C}_{3} \mathrm{H}_{5} \mathrm{NaOS}_{2}\right)$ ), used in mining as a collector for the enrichment of pyrite from quartz and galenite from sphalerite.

In $1000 \mathrm{~mL}$ of deionized water ( $\mathrm{L}=$ liquid) $20 \mathrm{~g}$ of the sample $(\mathrm{S}=$ sample) was added $(\mathrm{S}: \mathrm{L}$ ratio $=1: 50)$. With a pipette, 6 droplets of collector agent were added (one droplet for approx. $3 \mathrm{~g}$ of sample). In the flotation cell, the slurry mixture (more properly called the pulp) was stirred for approx. 10 min (Figure 3).

Then the froth reagent (sodium lauryl sulphate, SLS) was added. When foaming, the resulting bubbles/froth were instantly pulled into a separate dish. In the froth flotation, hydrophobic particles flow to the top and sepa- 


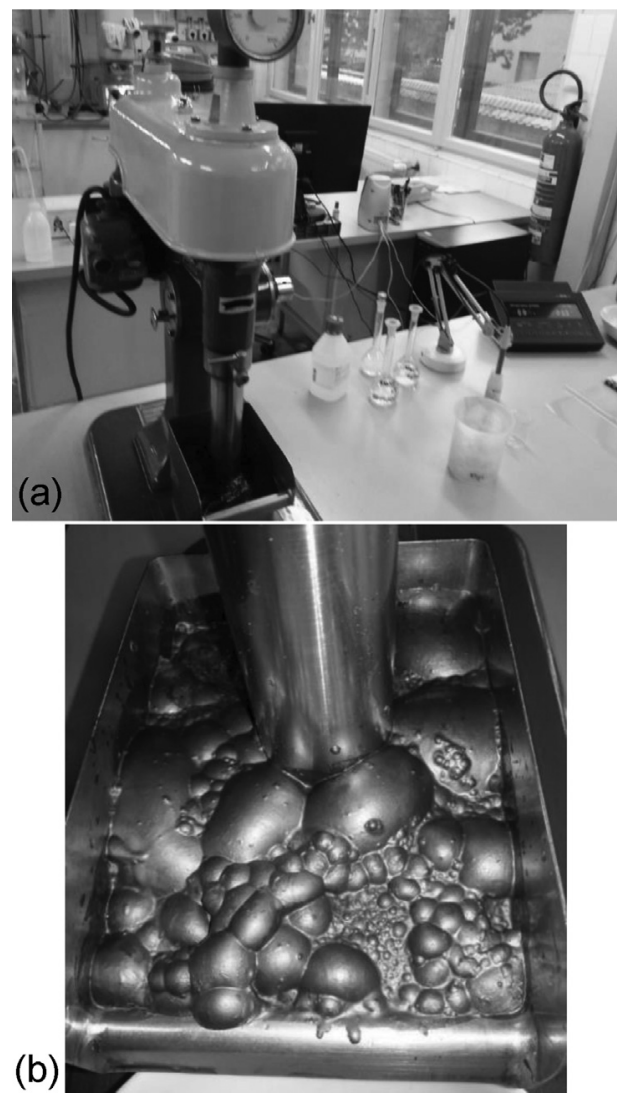

Figure 3: Denver flotation cell in operation (on the left) and sample flotation process with good adherence of carbon in the bubble-froth (on the right)

rate from the chamotte heavy particles. The process was repeated until the bubbles of the foam were transparent and lasted for approx. $1 \mathrm{~h}$. Samples from the metal container (carbon part and the remaining liquid sample) were stored separately, filtered, dried for $24 \mathrm{~h}$ and analysed for carbon content and for elements with an XRF instrument.

\section{Flotation test with an Ekofol reagent}

To further raise the carbon content of the remaining carbon part, a second flotation test was performed. The procedure was repeated with the difference that this time more sample was processed $(180 \mathrm{~g})$. In addition, instead of separate by used collector and froth reagents, the Ekofol 452 GK100 collector/froth agent was used, as performed by Schönfelder. ${ }^{15}$ The process lasted $42 \mathrm{~min}$ and 14 droplets of the agent were used. The sample was again separated on the silicate part on the bottom and the carbon part in the froth (Figure 3). After double drying, the two samples were subjected to a carbon-content and an XRF elemental analysis.

\subsection{Alkaline reactive extraction}

Afterwards, the test with the sample obtained from the flotation tests with the Ekofol reagent followed. The water washed SPL material contained almost no soluble salts and no silicates (bricks part); therefore, no flotation was needed anymore.

Finally, the alkali reactive leaching procedure was performed in an 1-M NaOH solution for $3 \mathrm{~h}$ with a $\mathrm{L}: \mathrm{S}$ ratio of 10:1. Subsequently, the samples were filtered and dried to define the carbon content.

Experiments were repeated with the "first cut" samples of SPL with rather a similar compound structure to further analyse the elementary and compound composition.

\subsection{Acidic reactive extraction}

To reduce the remaining calcium content and further increase the carbon content an acidic reactive extraction was performed. The remaining first cut alkali-extracted sample was washed with distilled water to avoid the alkali species contamination. Then the sample was filtered, dried and stirred at a speed of $500 \mathrm{~min}^{-1}$ in a 2.7-M HCl solution for $3 \mathrm{~h}$ in an L:S ratio of 10:1. The samples were again filtered, two-times water washed to avoid contamination, filtered and analysed.

Using a scanning electron microscope (SEM) analysis of the samples the morphology was determined.

An additional acidic test was carried out to compare the efficiency of the different types of acids. The first cut sample was subjected to the above-described water and alkali extraction. The alkali-leached sample was exposed to a $0.74-\mathrm{M} \mathrm{AlCl} \mathrm{Al}_{3}$ solution, in order to compare its effectiveness with respect to $\mathrm{HCl}$. Finally, both samples were water washed to avoid acidic contamination and analysed.

\section{RESULTS}

\section{Water extraction tests}

In a $1 \mathrm{~h}$ (time) period, almost all the soluble salts (mostly NaF) were extracted, representing about 20 to 30 mass \% of the entire sample. An additional $24 \mathrm{~h}$ of extraction did not increase the extracted mass significantly. In one leaching step, about 40 to 50 mass \% of fluorides and cyanides were extracted. Repeated extraction removed the residual soluble components (about 4 mass $\%$ of the whole soluble salts) and decreased the $\mathrm{pH}$. The XRF elemental analysis showed the greatest reduction in elements like sodium and fluoride (Table 2).

\section{Flotation results}

Double-dried samples after froth flotation with the collector and froth reagent were subjected to a carbon-content and an XRF elemental analysis. The carbon content of the silicate (brick) part was 4.06 mass \% with the main compounds quartz $\left(\mathrm{SiO}_{2}\right)$ and mullite $\left(\mathrm{Al}_{4} \mathrm{Si}_{6} \mathrm{O}_{10}\right)$. The carbon part contains 70 mass $\%$ of carbon and other compounds, merely quartz $\left(\mathrm{SiO}_{2}\right)$ with some minor content of cryolite $\left(\mathrm{Na}_{3} \mathrm{AlF}_{6}\right)$ and calcium 

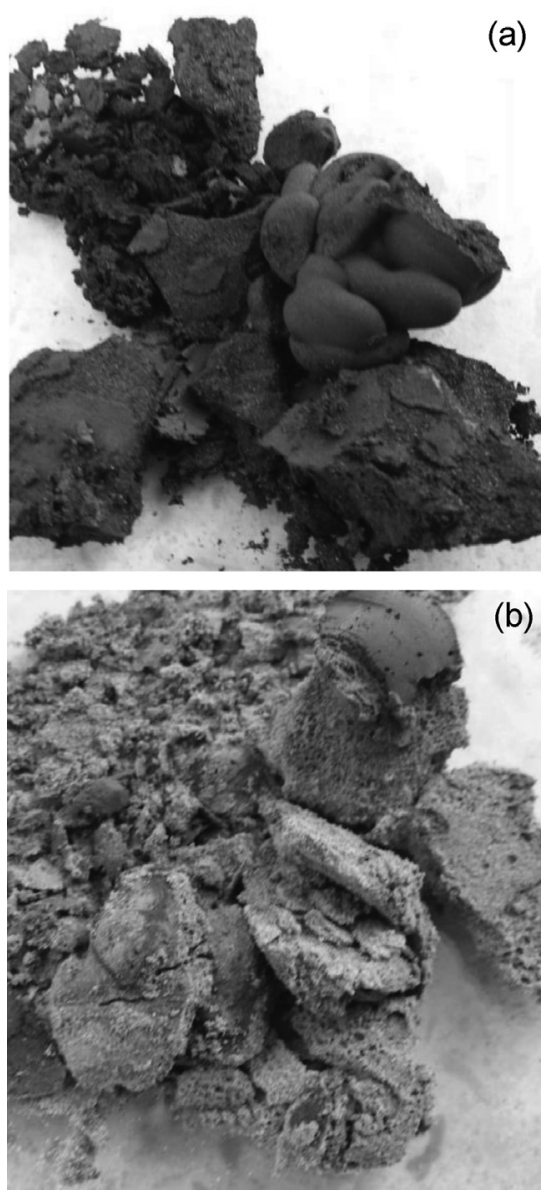

Figure 4: Obtained carbon part (left) and brick part (right) after water wash and flotation process

fluoride $\left(\mathrm{CaF}_{2}\right)$. The results are presented in Figure 4 (picture of the separated sample) and Figure 5 (diffractogram measurement results).

The reagent Ekofol 452 GK100, on the other hand, proved to be very effective because of the significantly better adherence of carbon (graphite and anthracite) to the surface of the bubbles. The Ekofol reagent has an
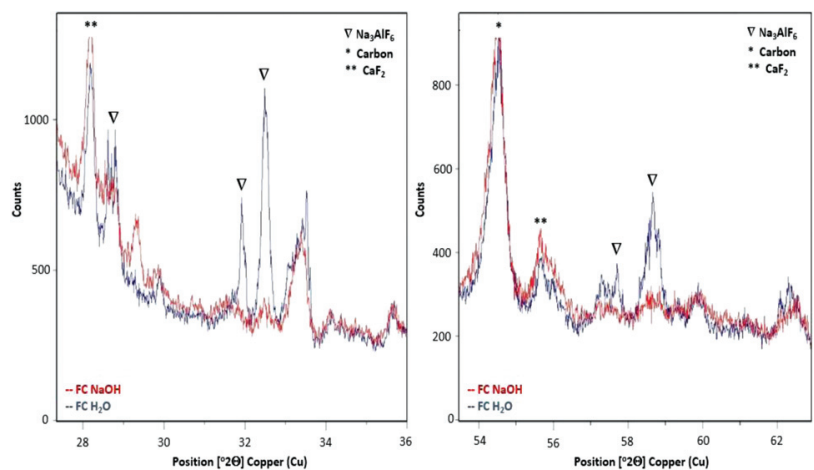

Figure 5: XRD diffractograms of an effective cryolite extraction: pixels: $29,32,32.5$ (left picture) and 57.8, 59.6 (right picture) have a lower value on the red line (alkaline extraction step). Crystallographic data from ICCD: carbon 00-008-415, CaF2 03-065-0535, cryolite 00-025-0772 about 4-times lower consumption and a 13-times shorter process time with respect to the collector and froth reagent.

The gained carbon part weighted $71 \mathrm{~g}$ and was subjected to a second-step flotation with the same procedure, using the Ekofol reagent. The process lasted 35 min and 4 Ekofol droplets were used. The secondstep flotation did not noticeably increase the carbon content. The problematic compounds are the following: cryolite $\left(\mathrm{Na}_{3} \mathrm{AlF}_{6}\right)$, calcium fluoride $\left(\mathrm{CaF}_{2}\right)$, gibbsite $\left(\mathrm{Al}(\mathrm{OH})_{3}\right)$ and diaoyudaoite $\left(\mathrm{NaAl}_{11} \mathrm{O}_{17}\right)$. The XRF analysis gives an elemental content of problematic species masses as follows: fluorine by $6 \%$, sodium by $2 \%$ and calcium by $1 \%$ (Table 2 ).

\section{Alkaline extraction tests}

The carbon-content analysis $\left(\mathrm{C}_{\mathrm{fix}}\right)$ after the alkaline reactive extraction procedure shows a significant rise from $72 \%$ to $82 \%$. The diffractogram analysis of the first-cut sample showed that with $\mathrm{NaOH}$ reactive extraction, removal of most of the cryolite in the waste sample was achieved (Figure 5). In addition, an elemental analysis made with the XRF clearly shows that elements like $\mathrm{F}, \mathrm{Na}$, and $\mathrm{Al}$, that constitute cryolite, did reduce significantly. On the other hand, the calcium fraction increased (Table 2).
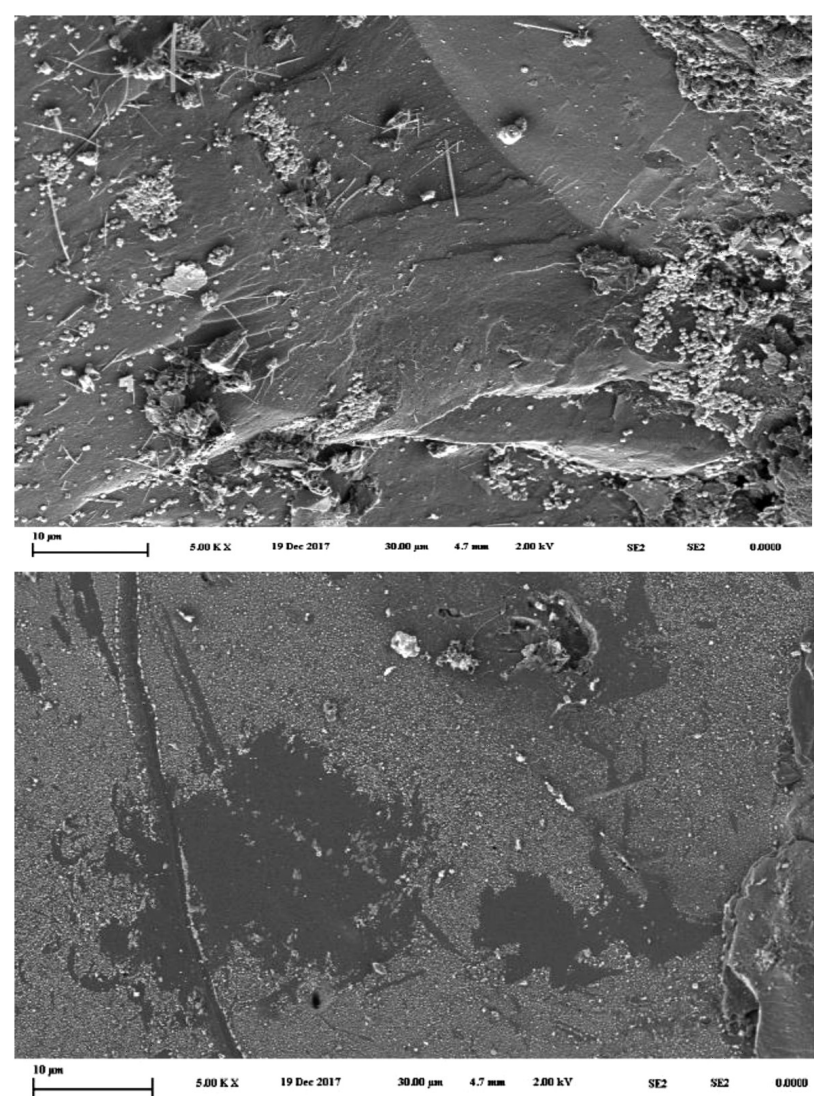

Figure 6: SEM analysis of water washed (left) and acid extracted sample (right) of the first cut 


\section{Acidic extraction tests}

The results after acidic extraction showed a significant reduction of the calcium content. The sample composition obtained by qualitative and quantitative analyses with the Rietveld analysis method is as follows $(w / \%)$ : $3.7 \% \mathrm{NaF}, 3.5 \%$ aluminium oxide hydrate, $1.4 \% \mathrm{CaF}_{2}$ and $0.7 \%$ Sodium aluminium oxide $\left(\mathrm{NaAl}_{11} \mathrm{O}_{17}\right)$. The remainder was $90.7 \%$ of graphite. The cryolite was removed completely, while the calcium fluoride and sodium aluminium oxide were significantly reduced.

SEM results (Figure 6) showed that there were almost no impurities left on the surface of the cleaned sample (after the acidic leaching step). There were very little traces of spherical and needle-shaped impurities in comparison to the first-cut sample, which was water washed only.

\section{$\mathrm{HCl}$ and $\mathrm{AlCl}_{3}$ efficiency comparison}

The carbon-content results in the $\mathrm{HCl}$ and $\mathrm{AlCl}_{3}$ efficiency comparison test showed approximately the same values $\left(\mathrm{C}_{\mathrm{fix}}\right.$ around 90 mass \%). In addition, the XRD diffractogram showed little changes in the species left in the sample. Both results also showed a significant drop in the $\mathrm{CaF}_{2}$ species.

\section{DISCUSSION}

A four-step treatment of SPL waste has been demonstrated as a suitable approach to obtain commercial products in the form of a high content of carbon and the silicate part. Water extraction is the most effective and simplest process to dissolve the soluble $\mathrm{NaF}$ impurities. These are part of the filtrate, which transforms to $\mathrm{CaF}_{2}$ and $\mathrm{NaOH}$ when exposed to lime (Equation 1). Both are desirable products in the metallurgical industry.

$$
2 \mathrm{NaF}+\mathrm{Ca}(\mathrm{OH})_{2}=2 \mathrm{NaOH}+\mathrm{CaF}_{2}
$$

A comparison between different flotation reagents in the same conditions shows a remarkable efficiency gap between the two reagents. After the second flotation the silicon-based components like $\mathrm{SiO}_{2}$ are significantly decreased as the insulation and firebrick parts are separated (Table 2). The froth-flotation efficiency is determined by a series of parameters: particle-bubble contact, particle-bubble attachment, transport between the pulp

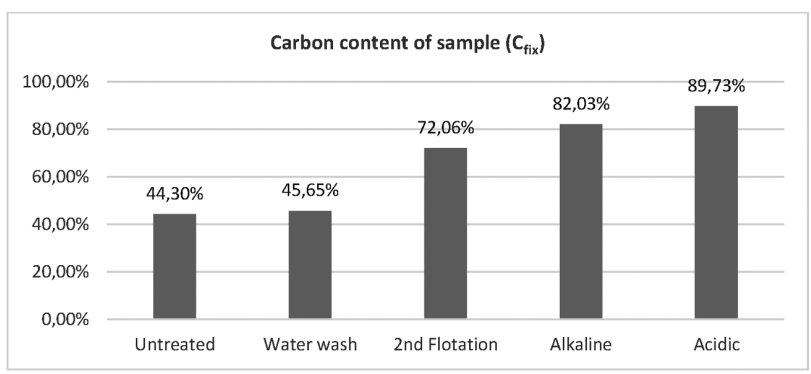

Figure 7: Fixed carbon $\left(\mathrm{C}_{\mathrm{fix}}\right)$ values in different treatment solutions and the froth, and froth collection into the product launder. In a conventional mechanically agitated cell (Denver flotation cell), the void fraction (i.e., the volume occupied by the air bubbles) is low (5 to 10 ) $\%$ and the bubble size is usually greater than $1 \mathrm{~mm}$. This results in a relatively low interfacial area and a low probability of particle-bubble contact. Consequently, several cells in series are required to increase the particle residence time, thus increasing the probability of particle-bubble contact and also improving the froth flotation efficiency.

The alkali extraction was successfully performed as $\mathrm{NaOH}$ was effectively decomposing the sparingly soluble cryolite salt. An additional reactive extraction with acid decomposes the calcium fluoride and sodium aluminium oxide and raises the carbon content of the sample up to $90 \%$ (Figure 7). The SEM images (Figure 6) show a clear difference in the quantity of the impurities on the surface of the treated and untreated samples.

The results showed that there is no significant difference between the acids $\mathrm{HCL}$ and $\mathrm{AlCl}_{3}$ extraction as the $\mathrm{AlCl}_{3}$ is changed to $\mathrm{HCl}$. Since $\mathrm{AlCl}_{3}$ is the more expensive compound, it is economically more appropriate to use $\mathrm{HCl}$ in the final extraction step.

\section{CONCLUSIONS}

The goal to produce purified carbon and silicate fractions from the SPL waste was achieved. The flotation results confirmed the optimal reagent choice as the separation of the silicate and carbon part was in both cases successful. The brick part is a usable product in firebrick production as it contains a reasonable part of mullite, alumina and silicates. The carbon part, on the other hand, has a high carbon content and is, therefore, a desirable product in the metallurgical industry.

Reactive extraction is proven to be an indispensable part of the process as higher purities of carbon were demanded. The by-product, i.e., the filtrate from water and alkali extraction, contains predominantly $\mathrm{NaF}$, which can be transformed to usable metallurgy compounds.

A former dangerous waste is now transformed into a safe and useful product at the plant site.

\section{Acknowledgements}

The authors would like to express their sincere gratitude to the University of Maribor, Faculty of Mechanical Engineering for the support and managing to unite interdisciplinary professions, and the University of Ljubljana, Faculty of Natural Sciences and Engineering, for providing the flotation tests and Talum d.d. (JSC) Kidričevo for providing the SPL samples and also for financial support for the analytics.

\section{REFERENCES}

${ }^{1}$ BREF Non - Ferrous Metals Industries, EC directorate-general JRC, Final Draft 10, NFM, 2014 
${ }^{2}$ J. Hop, A. Støre, T. Foosnæs, H. A. Øye, Chemical and physical changes of cathode carbon by aluminium electrolysis, VII International Conference on Molten Slags Fluxes and Salts, The South African Institute of Mining and Metallurgy, 2004, 775-782

${ }^{3}$ D. Mikša, M. Homšak, N. Samec, Spent potlining utilisation possibilities. Waste Manag. Res. 21 (2003) 467-473, doi:10.1177/ 0734242X0302100509

${ }^{4}$ R. P. Pawlek, Spent potlining: An update, Light Metals (2012), 1313-1317, doi:10.1007/978-3-319-48179-1_227

${ }^{5}$ M. L. G. Renó, F. M. Torres, R. J. da Silva, J. J. C. S. Santos, M. de Lourdes Noronha Motta Melo, Energy analyses in cement production applying waste fuel and mineralizer, Energy Conversion and Management (2013), doi:10.1016/j.enconman. 2013.05.043

${ }^{6}$ B. Meirelles, H. Santos, Economic and environmental alternative for destination of spent pot lining from primary aluminum production, Light Metals (2014), 565-570

${ }^{7}$ D. B. Turner, P. J. Binning, S. W. Sloan, A calcite permeable reactive barrier for the remediation of Fluoride from spent potliner (SPL) contaminated groundwater, Journal of Contaminant Hydrology 95 (2008), 110-120

${ }^{8}$ Z. Shi, W. Li, X. Hu, B. Ren, B. Gao, Z. Wang, Recovery of carbon and cryolite from spent pot lining of aluminium reduction cells by chemical leaching. Trans. Nonferrous Met. Soc. China, 22 (2012), 222-227, doi:10.1016/S1003-6326(11)61164-3

${ }^{9}$ X. Cao, Y. Shi, Z. Shung, X. Xue, Recovery of valuable components from spent pot lining of aluminium electrolytic reduction cells, Journal of Northeastern University (Natural Science), 35 (2014), 12

${ }^{10}$ L. D. F. Lisbona, K. M. Steel, Recovery of fluoride values from spent pot-lining: Precipitation of an aluminium hydroxyfluoride hydrate product, Separation and Purification Technology, 61 (2008), 182-192
${ }^{11}$ N. Ubong, S. Tait, E. T. White, K. M. Steel, The precipitation and solubility of aluminium hydroxyfluoride hydrate between 30 and $70{ }^{\circ} \mathrm{C}$, Hydrometallurgy, 155 (2015), 79-87

${ }^{12}$ T. K. Pong, R. J. Adrien, J. Besida, T. A. O’Donnell, D. G. Wood, Spent potlining - A hazardous waste made safe, Trans IChemE, Vol 78, Part B, 2000, 204-208

${ }^{13}$ D. F. Lisbona, C. Somerfield, K. M. Steel, Leaching of spent pot-lining with aluminum anodizing wastewaters: Fluoride extraction and thermodynamic modelling of aqueous speciation. Ind. Eng. Chem. Res., 51 (2012), 8366-8377, doi:10.1021/ie3006353

${ }^{14} \mathrm{D}$. Pankaj Indurkar, Optimization in the treatment of spent pot lining - A hazardous waste made safe, M. Tech Thesis, Chemical Engineering at National Institute of Technology, 2014

${ }^{15}$ I. Schönfelder, E. Gock, E. Tochtrop, S. Rieder, n.d., Recycling von Elektrolyseausbruch (SPL) aus der Primäraluminiumgewinnung 2014, 385-404

${ }^{16}$ W. Li, X. Chen, Development status of processing technology for spent potlining in China, Light Metals, (2010), 1064-1066

${ }^{17}$ G. Holywell, R. Breault, An overview of useful methods to treat, recover, or recycle spent potlining, JOM, 65 (2013), 1441-1451

${ }^{18}$ X. Chen, W. Li, Research on crushing character of spent cathode, Light Metals, 2007, 853-855

${ }^{19}$ M. Cenčič, I. Kobal, J. Golob, Thermal hydrolysis of cyanides in spent pot lining of aluminium electrolysis, Chem. Eng. Technol., 21 (1998), 523-532, doi:10.1002/(SICI)1521-4125(199806)21:6<523:: AID-CEAT523>3.0.CO;2-P 